\title{
THE MULTIPLE INTELLIGENCE BASED ENRICHMENT MODULE ON THE DEVELOPMENT OF HUMAN POTENTIAL: EXAMINING ITS IMPACT AND THE VIEWS OF TEACHERS
}

\author{
Nurulwahida Hj Azid @ Aziz¹, Aizan Yaacob \& \\ Sarimah Shaik-Abdullah \\ School of Education and Modern Languages \\ Universiti Utara Malaysia, Malaysia \\ ${ }^{1}$ Corresponding author: nurulwahida@uum.edu.my
}

\begin{abstract}
Purpose - Howard Gardners' concept of multiple intelligence (MI) offers an alternative perspective on intelligence which highlights the importance of acknowledging learner diversity, individual talents and the development of human potentials. MI has been used as a basis for the construction of modular enrichment activities to facilitate the development of human potential among boarding school students. This study examines (1) the effects of such activities on students of different multiple intelligence profiles and (2) the teachers' views of the MI based module and activities.
\end{abstract}

Methodology - The study employs a quasi-experimental design with pre- and post-tests administered before and after treatment of the modular enrichment activities. Two groups of students from two Mara Junior Science Colleges (MRSM) in Malaysia participated in the study as the control and treatment groups. McKenzie's multiple intelligences instrument was used as the pre- and post-test measure. A semi-structured interview protocol was used to obtain teachers' views of the enrichment activities.

Findings - The study found that the MI post-test was favourable towards the treatment group. Students in the treatment group improved on each multiple intelligence profile compared with students in the control group. The qualitative analysis of the interview 
data revealed favourable responses from the teachers towards the modular enrichment activities and the inclusion of MI.

Significance - This study highlights the importance of recognising that each student has his/her distinct potential. These differences can be captured through the construction of various enrichment activities that emphasise on the different multiple intelligences. The modular learning experience simplifies the process of teaching and learning. It enables students and teachers to understand the objectives to be achieved through diverse problem solving and creative production activities. It is hoped that through this study, educators and teachers will gain ideas about ways in which a MI perspective can help them to tap student potential.

Keywords: multiple intelligences, modular enrichment activities, quasi-experimental research design.

\section{INTRODUCTION}

In the field of education, the development of human potential is undeniably an important goal and this has been highlighted in the national philosophy of education in Malaysia in the following manner: "to develop individual potential holistically and in an integrated way in order to produce human capital that are intellectually, spiritually, emotionally, and physically balanced and harmonious" (Malaysia Ministry of Education, 2006). This aspiration calls for actions and joined forces from amongst various sectors in the Malaysian education system in order to materialise it (Nurulwahida \& Ahmad Azman, 2014).

The development of human potential, including the latent ones, can be tapped through appropriate stimulation and motivation. In the classroom context, this can be achieved through well-planned teaching and learning activities (Gardner, 2008 ; Sternberg, 2004). One example of such effort is the launch of the 'Schoolwide Enrichment Model' (SEM), by the MARA Junior Science College, a boarding school system in Malaysia. The main purpose of the SEM programme was to serve the need of diverse learners and to uncover real potential from among students of high 
academic abilities (Mohammad Amin, 2007 ; Nurulwahida, 2005). Mohammad Amin's (2007) examination of the SEM revealed that the programme was based on a three-phased activity approach: Phase 1 involved students' free and un-assessed exploration; phase 2 centred on skill-based activities; and phase 3 involved students doing research. Not all students were involved in all three phases, however. Participation in the third phase was limited to Form Five students (equivalent to grade 11, age 17) only. Mohammad Amin discovered that the teachers involved were not given guidelines to conduct the activities in phase 1 and the activities were loosely defined so much so that even a school trip was considered as phase 1 activity. Furthermore, the planning of the activities depended on teachers' initiative and creativity which was found to overburden the teachers. Despite the SEM's good intention, the conduct of the programme was found to be haphazard and unsystematic and was not based on any specific framework despite recognising the importance of individual differences.

The development of enrichment programmes such as the SEM can benefit from organised and systematic activities. One method is to build continuous learning and teaching materials in the form of modules (Valdez, Mangorsi, Hambre, Magdara \& Manalundong, 2013). This can be achieved by employing modular presentations of activities (Farland, 2006), in which teaching and learning activities are presented sequentially with topics broken down into several subtopics to increase usability and readability (Mayer, 1988). In order to highlight the importance of learner diversity, the enrichment activities can be build based on the theory of multiple intelligence (MI) which acknowledges individual differences according to eight different intelligence constructs (Gardner, 2004; Sternberg, 2004; Owalabi \& Okebukola, 2009). This study, therefore, was intended to examine the effectiveness of MI based modular enrichment activities in increasing student potential.

\section{PURPOSE OF STUDY}

In this study, it is assumed that, following Gardner (2008), the development of human potential can be facilitated through the implementation of the MI-based modular enrichment activities. The development of student potential is deemed observable by 
examining the student MI profile before and after the treatment. This study, therefore, has examined the effect of the modular enrichment activities on the different student multiple intelligence profiles. Gardner (2004) has postulated that human intelligence could be categorised into eight types of intelligences: verbal linguistic, logical-mathematical, visual-spatial, bodily-kinesthetic, musical, interpersonal, intrapersonal and naturalist. Gardner (2008) argued that the development of intellectual capabilities was dependent on the combination of cognitive abilities and multiple intelligences. Based on Gardner's suggestion, this study has looked for all eight intelligences in the problem solving activities observed. It is hoped that through this study, educators and teachers would gain ideas about ways to tap student potential through MI.

\section{RESEARCH QUESTIONS AND HYPOTHESES}

This study has posed the following three research questions:

1. What multiple intelligence profiles can be identified among the students in the MARA Junior Science College selected for this study?

2. Are there significant differences in the eight multiple intelligence profiles between the control and treatment groups of MARA students?

3. What are the teachers' views of the MI-based modular enrichment activities?

To answer the second research question, eight null hypotheses were formulated based on the eight MI profiles and summarised in the following manner: There are no significant differences between the control and treatment groups on any of the MI construct measures.

\section{DEFINITIONS AND CONCEPTUALISATION OF MULTIPLE INTELLIGENCES IN THE MODULAR ENRICHMENT ACTIVITIES}

Gardner's (1996) definitions of the different types of MI and how each MI is conceptualised in the development of the module are discussed next: (A) Verbal linguistic intelligence refers to the 
ability to use language effectively, and this includes the ability to recognise nuances in meanings of words, write argumentative papers and listen to poetry recitals. In the enrichment programme, unit one that covers verbal linguistic intelligence incorporates verbal activities such as group discussions, interactive games, creative writing, crossword puzzles and analysis of texts based on scenarios provided. (B) Logical-mathematical intelligence refers to the ability to reason logically, calculate and solve problems involving numbers and number systems. The enrichment activities are included in unit two of the module and involves activities such as mathematical and logic games, analysis of information, plotting information into graphic forms, constructing analogies, and evaluating facts. (C) Visual spatial intelligence relates to the ability to think in terms of the visuals and images. Students with this kind of ability are able to transfer their world view into mental images, design and manipulate patterns, colours and shapes. The enrichment activities based on visual spatial intelligence comprise components that relate to detecting the details in shapes, colours and objects. The activities involve students having to visualise and manipulate objects in the mind and to think through diagrams and figures in order to deliver information and solve problems. (D) Bodily-kinesthetic intelligence is the ability to use one's body skilfully. Unit four in the enrichment module contains activities that involve physical movements. This activity also allows students to think physically by relating to various bodily movements such as writing for sports and by communicating messages using sign language. Students have the opportunity to mimic the movement of animals through a variety of animal games without using voice or sound. (E) Musical intelligence refers to listening and auditory intelligence. It involves the ability to create, comprehend and appreciate music and to recognise rhythm, tone and melody. The enrichment module activities for unit five includes activities that allow students to complete sudoku music game, create and sing songs, and write commentaries about music related issues. (F) Interpersonal intelligence is the ability to understand and interact with others through effective communication. Students with this intelligence are able to work well in groups and are able to lead, be sensitive to others' feelings and motivation, and recognise and categorise the behaviours of others. Interpersonal intelligence as used in the enrichment program, involves components related to student relationships with others, such as working in teams, 
communicating with team members, and solving problems as a team. The module includes activities in which students learn to sensitise to other people's feelings, like when they are preparing speeches for teachers, remaining loyal towards friends and avoiding situations that can cause conflicts. (G) Intrapersonal intelligence is also known as self-smart. Students with this ability are usually able to understand their own feelings, emotions and needs, reach out to inner feelings, and engage in self-reflections. The enrichment activities in the module that relate to intrapersonal intelligence involve activities such as setting goals and the direction of life now and for the future, and express feelings, opinions and ideas to solve problems. The unit includes writing activities for individuals to express their ideas, make entries into reflective journals about themselves, and state plans to achieve their ambitions. Individually, students are able to express feelings and opinions about the narrative texts given. $(\mathrm{H})$ Naturalist intelligence is the ability to identify and classify the components that make up the environment and natural objects. The enrichment activities based on naturalistic intelligence in unit eight covers issues relating to students' sensitivity to the environment and their general knowledge of the environment and its flora and fauna. In this unit, students are expected to be taken outdoor to find specimens of plants and make reports on the textures and characteristics including colours, types, locations and the name of each section of the specimen. Students are also involved in researching and observing weather conditions and weather reports and making diary entries. Additionally, students are encouraged to participate in the environmental quiz in conjunction with World Earth Day, and plan writing activities related to pollution and environmental degradation due to unplanned developments.

The MI based enrichment activities were offered to students of high academic ability in the college as an addition to the already existing programmes. It is aimed to actualise students' contributions to the self and the society through their various distinct potential. Each unit in the module was arranged neatly according to the eight MI (see appendix for the sample module unit). In addition, the construction of the enrichment module which was based on and measurable according to specific objectives, learning outcomes, and procedures for implementation was expected to stimulate teachers to build more MI based enrichment activities in the future. 


\section{RESEARCH METHODOLOGY}

A quasi-experimental design was employed in this study, since it was acknowledged that full control over extraneous variables was not possible when carried out in social and educational settings (Creswell, 2012). The design of this study is as shown in Figure 1.

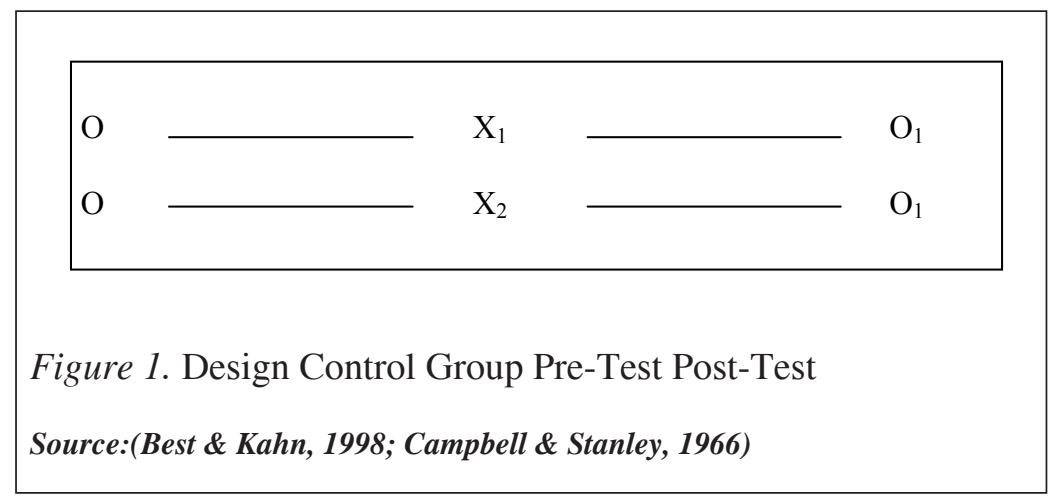

Keys:

$\mathrm{X}_{1} \quad$ - Conventional enrichment activities

$\mathrm{X}_{2} \quad$ - Multiple intelligence module enrichment activities

$\mathrm{O} \quad$ - Pre-test

$\mathrm{O}_{1} \quad$ - Post-test

In the first week of the study, Gardner's multiple intelligence test (O) was administered on the control group (X1) and treatment group (X2). The control and treatment groups involved Form Four (16-year-old) students from two different colleges (MRSM 1 and MRSM 2). Three weeks after the pre-test, the treatment group (X2) underwent the one month MI-based enrichment programme, while the control group (X1) underwent the conventional enrichment programme based on the Renzuli model (1985) and for a similar duration. Following this, a post-test was conducted, in accordance with Campbell and Stanley's (1966) recommendation that the gap between the pre and post tests should be about one to two months. The treatment group consisted of 28 students, while the control group had 29. Convenience sampling was applied in the selection of the students. This was because in the Malaysian education system, students remain intact in the same classroom for a period of one 
year. As such, the selection of students by achievement is always done at the beginning of the school year. The size of both treatment and control groups was considered adequate to obtain statistically substantial data (Field, 2009). ANCOVA analysis was applied to compare the mean values of the treatment and control groups before and after treatment (Chua, 2009; Field, 2009).

Before the treatment was given, all the teachers involved $(n=4)$ in the treatment group attended a one-day training on the use of the module. This training was conducted by one of the researchers. The researcher cum trainer detailed out all the activities involved and engaged the teachers in dialogic discussions to facilitate understanding and clarify matters relating to the use of the module in the classroom. Confusions and foreseen difficulties were collaboratively attended to and ideas were generated as contingencies. During the treatment period of the study, each of the four teachers were involved in two ways: (1) directly implementing two selected units in the MI module in their teaching, and (2) observing and giving feedback on the other teachers' application of the remaining units, using an observational checklist prepared by the researchers.

Qualitative data were collected through semi-structured interviews with the four teachers (Merriam, 2009). Because of their dual involvement in the study, each teacher was interviewed on their experience using the modules and on their observation of the activities. The interviews were audio-recorded, transcribed and thematically analysed to generate themes to reflect the teachers' views about the module in general and about the activities in particular (Braun and Clarke, 2013).

\section{Homogeneity Test}

Leven's homogeneity test was carried out on the eight preprofiling of the multiple intelligence test. The results indicated that there was no significant difference between the groups. This showed that multiple intelligence profiles of both groups were similar at the outset. Results of the Levene's test were as follows: verbal linguistic intelligence $[\mathrm{F}(2,84)=.404, \mathrm{p}>.05]$, Logical mathematics intelligence $[\mathrm{F}(2,84)=.470, \mathrm{p}>.05]$, visual spatial intelligence $[\mathrm{F}(2,84)=.755, \mathrm{p}>.05]$, bodily-kinesthetic intelligence $[\mathrm{F}(2,84)=.939, \mathrm{p}>.05]$, musical intelligence $[\mathrm{F}(2,84)=1.130, \mathrm{p}>.05]$, 
interpersonal intelligence $[\mathrm{F}(2,84)=1.146, \mathrm{p}>.05]$, intrapersonal intelligence $[\mathrm{F}(2,84)=1.978, \mathrm{p}>.05]$ and naturalist intelligence $[\mathrm{F}(2,84)=1.052, \mathrm{p}>.05]$. The Levene's test results on the eight multiple intelligences indicated that they were not significant, the null hypothesis failed to be rejected. There was no variance in the pre-test for all the categories tested.

\section{RESEARCH FINDINGS}

\section{Profiles of MRSM Students}

Table 1 shows the findings of the pre-test and post-test profiles of the control group. The rationale for creating the multiple intelligence profile was that there was no data available on the multiple intelligence profile of the MARA Junior Sciences Colleges under study. Overall, the pre-test results showed Excellent results for intrapersonal intelligence $65.5 \%(\mathrm{n}=19)$, interpersonal intelligence $51.7 \%(\mathrm{n}=15)$, and logical mathematics intelligence $41.3 \%(\mathrm{n}=12)$. Meanwhile the post-test showed inconsistent results for the control group in all the eight intelligences. Post-test results indicated Excellent category only for interpersonal and intrapersonal intelligences with $31.0 \%(n=9)$. The control group recorded the highest number of students having low scores in musical intelligence $31.0 \%(\mathrm{n}=9)$, and naturalist intelligence $27.5 \%(\mathrm{n}=8)$.

Table 1

Pre-Test and Post-Test Profiles of the Control Group

\begin{tabular}{cccccc}
\hline \multirow{2}{*}{ Intelligence } & \multirow{2}{*}{ Category } & \multicolumn{2}{c}{ Pre-Test } & \multicolumn{2}{c}{ Post-Test } \\
\cline { 3 - 6 } & & $\boldsymbol{f}$ & $\%$ & \multicolumn{1}{c}{$\boldsymbol{f}$} & $\%$ \\
\hline \multirow{4}{*}{ Verbal Linguistic } & Excellent & 3 & 10.3 & 2 & 6.8 \\
& Satisfactory & 14 & 48.2 & 8 & 27.5 \\
& Average & 8 & 27.5 & 16 & 55.1 \\
& Low & 4 & 13.7 & 3 & 10.3 \\
Logical & Excellent & 12 & 41.3 & 4 & 13.7 \\
Mathematic & Satisfactory & 8 & 27.5 & 12 & 41.3 \\
& Average & 9 & 31.0 & 12 & 41.3 \\
& Low & 0 & .0 & 1 & 3.4 \\
\hline & & & & & (continued)
\end{tabular}




\begin{tabular}{|c|c|c|c|c|c|}
\hline \multirow{2}{*}{ Intelligence } & \multirow{2}{*}{ Category } & \multicolumn{2}{|c|}{ Pre-Test } & \multicolumn{2}{|c|}{ Post-Test } \\
\hline & & $f$ & $\%$ & $f$ & $\%$ \\
\hline \multirow{4}{*}{ Visual Spatial } & Excellent & 9 & 31.0 & 2 & 6.8 \\
\hline & Satisfactory & 16 & 55.1 & 15 & 51.7 \\
\hline & Average & 2 & 6.8 & 8 & 27.5 \\
\hline & Low & 2 & 6.8 & 4 & 13.7 \\
\hline \multirow{4}{*}{ Kinesthetic } & Excellent & 5 & 17.2 & 4 & 13.7 \\
\hline & Satisfactory & 18 & 62.0 & 9 & 31.0 \\
\hline & Average & 4 & 13.7 & 11 & 37.9 \\
\hline & Low & 2 & 6.8 & 5 & 17.2 \\
\hline \multirow{4}{*}{ Musical } & Excellent & 6 & 20.6 & 3 & 10.3 \\
\hline & Satisfactory & 13 & 44.8 & 10 & 34.4 \\
\hline & Average & 4 & 13.7 & 7 & 24.1 \\
\hline & Low & 6 & 20.6 & 9 & 31.0 \\
\hline \multirow{4}{*}{ Interpersonal } & Excellent & 15 & 51.7 & 9 & 31.0 \\
\hline & Satisfactory & 10 & 34.4 & 10 & 34.4 \\
\hline & Average & 3 & 10.3 & 6 & 20.6 \\
\hline & Low & 1 & 3.4 & 4 & 13.7 \\
\hline \multirow{4}{*}{ Intrapersonal } & Excellent & 19 & 65.5 & 9 & 31.0 \\
\hline & Satisfactory & 8 & 27.5 & 15 & 51.7 \\
\hline & Average & 1 & 3.4 & 5 & 17.2 \\
\hline & Low & 1 & 3.4 & 0 & 0 \\
\hline \multirow{4}{*}{ Naturalist } & Excellent & 2 & 6.8 & 2 & 6.8 \\
\hline & Satisfactory & 9 & 31.0 & 5 & 17.2 \\
\hline & Average & 16 & 55.1 & 14 & 48.2 \\
\hline & Low & 2 & 6.8 & 8 & 27.5 \\
\hline
\end{tabular}

Table 2 indicates the pre-test and post-test profiles of the treatment group. Overall, the treatment group showed improvement in most of the intelligences except for logical mathematics and interpersonal intelligences. Excellent scores were recorded in the visual spatial category, which improved from $10.7 \%(\mathrm{n}=3)$ to $25 \%$ $(\mathrm{n}=7)$, kinesthetic intelligence from $7.1 \%(\mathrm{n}=2)$ to $25 \%(\mathrm{n}=7)$, and naturalist intelligence from $3.5 \%(n=1)$ to $17.8 \%(n=5)$. Meanwhile, the low scores recorded in musical intelligence decreased from $25 \%$ $(\mathrm{n}=7)$ to $3.5 \%(\mathrm{n}=1)$, logical mathematics from $17.8 \%(\mathrm{n}=5)$ to $7.1 \%$ $(\mathrm{n}=2)$, interpersonal intelligence from $14.2 \%(\mathrm{n}=4)$ to $7.1 \%(\mathrm{n}=2)$ and naturalist intelligence from $32.1 \%(n=9)$ to $14.2 \%(n=4)$. 
Table 2

Pre-Test and Post-Test Profiles of the Treatment Group

\begin{tabular}{|c|c|c|c|c|c|}
\hline \multirow{2}{*}{ Intelligence } & \multirow{2}{*}{ Category } & \multicolumn{2}{|c|}{ Pre-Test } & \multicolumn{2}{|c|}{ Post-Test } \\
\hline & & $f$ & $\%$ & $f$ & $\%$ \\
\hline \multirow{4}{*}{ Verbal Linguistic } & Excellent & 0 & .0 & 2 & 7.1 \\
\hline & Satisfactory & 8 & 28.5 & 11 & 39.2 \\
\hline & Average & 14 & 50.0 & 12 & 42.8 \\
\hline & Low & 6 & 21.4 & 3 & 10.7 \\
\hline \multirow{4}{*}{ Logical Mathematic } & Excellent & 4 & 14.2 & 1 & 3.5 \\
\hline & Satisfactory & 11 & 39.2 & 16 & 57.1 \\
\hline & Average & 8 & 28.5 & 9 & 32.1 \\
\hline & Low & 5 & 17.8 & 2 & 7.1 \\
\hline \multirow{4}{*}{ Visual Spatial } & Excellent & 3 & 10.7 & 7 & 25 \\
\hline & Satisfactory & 12 & 42.8 & 11 & 39.2 \\
\hline & Average & 11 & 39.2 & 7 & 25 \\
\hline & Low & 2 & 7.1 & 3 & 10.7 \\
\hline \multirow{4}{*}{ Kinesthetic } & Excellent & 2 & 7.1 & 7 & 25 \\
\hline & Satisfactory & 8 & 28.5 & 10 & 35.7 \\
\hline & Average & 16 & 57.1 & 7 & 25 \\
\hline & Low & 2 & 7.1 & 4 & 14.2 \\
\hline \multirow{4}{*}{ Musical } & Excellent & 2 & 7.1 & 4 & 14.2 \\
\hline & Satisfactory & 13 & 46.4 & 9 & 32.1 \\
\hline & Average & 6 & 21.4 & 14 & 50 \\
\hline & Low & 7 & 25 & 1 & 3.5 \\
\hline \multirow{4}{*}{ Interpersonal } & Excellent & 6 & 21.4 & 7 & 25 \\
\hline & Satisfactory & 10 & 35.7 & 12 & 42.8 \\
\hline & Average & 8 & 28.5 & 7 & 25 \\
\hline & Low & 4 & 14.2 & 2 & 7.1 \\
\hline \multirow{4}{*}{ Intrapersonal } & Excellent & 8 & 28.5 & 7 & 25 \\
\hline & Satisfactory & 11 & 39.2 & 14 & 50 \\
\hline & Average & 8 & 28.5 & 5 & 17.8 \\
\hline & Low & 1 & 3.5 & 2 & 7.1 \\
\hline \multirow{4}{*}{ Naturalist } & Excellent & 1 & 3.5 & 5 & 17.8 \\
\hline & Satisfactory & 6 & 21.4 & 8 & 28.5 \\
\hline & Average & 12 & 42.8 & 11 & 39.2 \\
\hline & Low & 9 & 32.1 & 4 & 14.2 \\
\hline
\end{tabular}


Table 3 shows the comparison of the mean scores for the posttest between the control and the treatment groups. As indicated, the mean scores for the post-test of the treatment group in verbal linguistic, visual spatial, bodily-kinesthetic, musical, interpersonal and naturalistic intelligences surpassed the control group. However, in logical mathematic and intrapersonal intelligences, the control group's mean scores were higher than the treatment group.

Table 3

Comparison of the Post-Test between the Treatment and the Control Groups

\begin{tabular}{lcc}
\hline \multicolumn{1}{c}{ Intelligence } & \multicolumn{2}{c}{ Mean } \\
& Control & Treatment \\
\hline Verbal Linguistic & 60.34 & 64.28 \\
Logical Mathematic & 69.65 & 66.78 \\
Visual Spatial & 65.86 & 70.71 \\
Kinesthetic & 63.10 & 70.00 \\
Musical & 57.24 & 67.14 \\
Interpersonal & 68.95 & 71.78 \\
Intrapersonal & 78.27 & 73.21 \\
Naturalist & 55.51 & 65.00 \\
\hline
\end{tabular}

Table 4 shows the ANCOVA results of the post-test. The results were as follows: The ANCOVA result shows that there was a major effect of the independent variable of the sample group which was significant towards the post-test of the dependent variable in verbal linguistic intelligence $[\mathrm{F}(1,54)=4.99, \mathrm{p}<.05]$; visual spatial intelligence $[\mathrm{F}(1,54)=9.06, \mathrm{p}<.05]$; bodily-kinesthetic intelligence $[\mathrm{F}(1,54)=11.53, \mathrm{p}<.05]$; musical intelligence $[\mathrm{F}(1,54)=8.74, \mathrm{p}<.05]$; interpersonal intelligence $[\mathrm{F}(1,54)=7.96, \mathrm{p}<.05] ;$ and naturalist intelligence $[\mathrm{F}(1,54)=9.54, \mathrm{p}<.05]$.

In addition, there was a significant major effect on the pre-test of the controlled variable towards the post-test of the dependent variable of the verbal linguistic intelligence $[\mathrm{F}(1,54)=12.82, \mathrm{p}<.05]$; visual spatial 
intelligence $[\mathrm{F}(1,54)=32.61, \mathrm{p}<.05]$; bodily-kinesthetic intelligence $[\mathrm{F}(1,54)=27.12, \mathrm{p}<.05]$; musical intelligence $[\mathrm{F}(1,54)=49.91, \mathrm{p}<.05]$; interpersonal intelligence $[\mathrm{F}(1,54)=40.84, \mathrm{p}<.05]$ and naturalist intelligence $[\mathrm{F}(1,54)=19.41, \mathrm{p}<.05]$. Based on the result, the null hypotheses were rejected.

The pair comparison test result of the post-test of verbal linguistic, visual spatial, bodily-kinesthetic, musical, interpersonal and naturalist indicated that after controlling the Type 1 error using Bonferroni method, the pair comparison of the treatment-controlled group (the mean difference of verbal linguistic intelligence $=$ $8.17, \mathrm{p}<0.5$ ); (the mean difference of visual spatial $=11.71, \mathrm{p}<.05$ ); (the mean difference of bodily-kinesthetic $=15.03, \mathrm{p}<.05)$; (the mean difference of musical intelligence $=9.90, \mathrm{p}<.05$ ); (the mean difference of the interpersonal intelligence $=2.83, \mathrm{p}<.05)$ and (the mean difference of the naturalist intelligence $=9.49, \mathrm{p}<.05$ ) generated significant results. The results confirmed that there was a major effect of the independent variables on the dependent variables of the post-test. This significantly indicated that the post-test scores of the treatment group surpassed the control group. The findings seemed to suggest that the enrichment activities based on MI module had provided a significant impact on the students' multiple intelligences.

In addition, the ANCOVA test showed that there was no significant effect of the independent variable on the dependent variable in the post-test for logical mathematics $[\mathrm{F}(1,54)=1.123, \mathrm{p}>.05]$ and intrapersonal intelligences $[\mathrm{F}(1,54)=.46, \mathrm{p}>.05]$. However, the control variable of the pre-test for logical mathematic provided a major impact on the dependent variables of the post-test for logical mathematic $[\mathrm{F}(1,54)=31.82, \mathrm{p}<.05]$ and intrapersonal intelligences $[\mathrm{F}(1,54)=18.94, \mathrm{p}<.05]$. The results of comparison between treatment-control groups confirmed that they were not significant as a whole. Based on this finding, the researchers failed to reject the null hypotheses (Ho2 and Ho7). The results seemed to suggest that the enrichment activities did not influence the post-test profile of the logical mathematics and intrapersonal intelligences of the students. 
Table 4

ANCOVA Post-Test Multiple Intelligence Profile

\begin{tabular}{cccccc}
\hline Resources & $\begin{array}{c}\text { Total } \\
\text { Squares } \\
\text { Type III }\end{array}$ & Df & $\begin{array}{c}\text { Mean } \\
\text { Square }\end{array}$ & F & Sig. \\
& & & \\
\hline
\end{tabular}

Dependent Variable: Post-Test Profile of Verbal Linguistic Intelligence

$\begin{array}{lccccc}\text { Pre-Test Profile Verbal linguistic } & 2183.859 & 1 & 2183.859 & 12.821 & .001 \\ \text { Sample Group } & 850.441 & 1 & 850.441 & 4.993 & .030\end{array}$

Dependent Variable: Post-Test Profile of Logical Mathematics Intelligence

$\begin{array}{lccccc}\text { Pre-Test Profile Logical Mathematics } & 4118.086 & 1 & 4118.086 & 31.817 & .000 \\ \text { Sample Group } & 145.321 & 1 & 145.321 & 1.123 & .294\end{array}$

Sample Group

Dependent Variable: Post-Test Profile of Visual Spatial Intelligence

$\begin{array}{llllll}\text { Pre-Test Profile Visual Spatial } & 6358.888 & 1 & 6358.888 & 32.609 & .000 \\ \text { Sample Group } & 1766.532 & 1 & 1766.532 & 9.059 & .004\end{array}$

Dependent Variable: Post-Test Profile of Kinesthetic Intelligence

$\begin{array}{lllllll}\text { Pre-Test Profile Kinesthetic } & 6626.018 & 1 & 6626.018 & 27.117 & .000\end{array}$

$\begin{array}{llllll}\text { Sample Group } & 2817.251 & 1 & 2817.251 & 11.530 & .001\end{array}$

Dependent Variable: Post-Test Profile of Musical Intelligence

$\begin{array}{lccccc}\begin{array}{l}\text { Pre-Test Profile } \\ \text { Musical }\end{array} & 11024.361 & 1 & 11024.361 & 49.916 & .000 \\ \text { Sample Group } & 1930.398 & 1 & 1930.398 & 8.740 & .005\end{array}$

Dependent Variable: Post-Test Profile of Interpersonal Intelligence

$\begin{array}{llllll}\text { Pre-Test Profile Interpersonal } & 8992.181 & 1 & 8992.181 & 40.848 & .000 \\ \text { Sample Group } & 1752.360 & 1 & 1752.360 & 7.960 & .007\end{array}$

Dependent Variable: Post-Test Profile of Intrapersonal Intelligence

$\begin{array}{lllllll}\text { Pre-Test Profile Intrapersonal } & 3590.321 & 1 & 3590.321 & 18.944 & .000\end{array}$

$\begin{array}{llllll}\text { Sample Group } & 87.170 & 1 & 87.170 & .460 & .501\end{array}$

Dependent Variable: Post-Test Profile of Naturalist Intelligence

$\begin{array}{lllllll}\text { Pre-Test Profile Naturalist } & 4977.056 & 1 & 4977.056 & 19.419 & .000\end{array}$

\begin{tabular}{llllll} 
Sample Group & 2446.296 & 1 & 2446.296 & 9.545 & .003 \\
\hline
\end{tabular}

\section{Teachers' views on the MI-based module and enrichment activities}

This section reports findings from the analysis of the interview data gathered from the MRSM teachers who applied the enrichment activities to the treatment group. The aim of the interview was to 
obtain their perspectives (as observers and as implementers) on the MI-based module and the enrichment activities. Two male and two female teachers (identified as R1, R2, R3 and R4) teaching Mathematics, History, Geography and English respectively, were interviewed. All of them had had at least three years of teaching experience. The data analysis revealed the following major themes as regards the teachers' views on aspects of the module and the enrichment activities: Teacher realisation of learner differences, opportunity for students to self-assess, active student engagement, module elements, and future recommendations.

\section{Teacher realisation of learner differences}

Repeatedly found among the four teachers was their sense of realisation that students were naturally different in their inclinations. The experience of applying the module contents and activities and observing other colleagues' application of them provided the teachers with moments to reflect on the differences that were observed among their students in terms of skills, strengths and inclinations. This was evidenced in RI's reflection of the matter:

I can see clearly students' inclinations towards certain intelligence. I realise and believe that each student has various and unique intelligences. (R1)

Besides having the realisation that students were diverse, as shown through the activities that the teachers encountered during the experimental stage of the study, the teachers seemed to agree that there were indeed ways to promote and celebrate individual differences in the classroom. The contents and activities in the module illustrated the various ways that teachers could use to cater for different intelligences.

After using this module, I realised that there are many enrichment activities that can be created for high achievers like MRSM students by applying different aspects of intelligence. (R2)

I think this module can help teachers to respond to learner differences during enrichment activities. (R3) 


\section{Opportunity for students to self-assess}

Besides recognising the importance of MI, there were repeated mentions of the potential usefulness of the module and activities as a way to facilitate students to self-assess in terms of their strengths and to know themselves.

For students, they can realise their own intelligences and experience activities that suit their inclinations. I think students will appreciate their strengths (potentials) and work hard to improve their weak intelligence. (R3)

Furthermore, students can identify their own strengths which they may not have realised before. For their weaknesses which they have discovered, they may try to improve it in the future. ... This module is useful for students' daily lives when they know their intelligences. (R4)

According to the teachers, the modular enrichment activities provided the students with opportunities to assess their own potential and strengths. In this way, the teachers had suggested that the students might be able to independently identify their own strengths and weaknesses and planned ways to improve themselves, work hard and take initiatives to improve their "weak" intelligences. Furthermore, as suggested by R4, awareness of their own intelligences could benefit students' daily lives.

\section{Active student engagement}

All four teachers mentioned that the MI based enrichment activities induced active engagement among the students.

I'm happy to see the students so actively involved in all the activities provided. (R2)

This module manages to attract active participation from the students because it is creative and different. Most importantly, this module provides many activities that arouse teachers' and students' interests. ... It can stimulate students' thinking skills, critical thinking and social skills. (R4)(R4)

The students enjoyed them and they are not bored. (R1) 
The above interview excerpts seemed to suggest that there was better involvement of students in the modular enrichment activities offered in this study as compared to their involvement in the traditional class and in other enrichment activities "before this" (R2). The students were active, showed interest, and were not bored. Besides making learning "very fun" (R1), the activities in this study also provided opportunities for students to apply higher order thinking skills as they worked together.

\section{Module elements}

The teachers also gave their views about the module content, activities and presentation, according to the following sub-themes:

Clear objectives and instructions:

I notice that this module has many positive elements. Among them are clear objectives and steps, and the learning outcomes are easy to understand. (R2)

Variety of activities:

I notice that activities like quiz, sudoku, weather diary and nature observation aroused students' interests and attention. (R4)

To me the activities vary and were developed to suit different MI's. For example, there are activities like games and quizzes. ... Many activities relate to students' lives. (R1)

The teachers perceived the usefulness of the module in terms of its ease of use. The objectives were clear and achievable, and the steps too were clearly explained to enable the teachers to apply the activities in the classroom. At the same time, the module appealed to the teachers as it contained various activities to attract the students' interests by integrating visuals, pictures, charts, graphs, short stories and games to fulfil the strategies for multiple learning resources. Finally, as pointed out by R1, the activities were able to relate to students' lives. 


\section{Recommendations for future use}

The teachers recommended the use of the module in different contexts and this was because, as according to R3, it might enable teachers to use the information gained from the module activities to respond to the different student needs and to recognise student strengths and potential. Furthermore, the module was recommended for future use because it could facilitate teachers in assessing student intelligences. The following excepts illustrate the two recommendations made by the teachers.

It provides activities which involve a lot of skills and can be introduced to government schools too. ... This module can be implemented in KIKA or MIGTY programmes (existing programmes) in MRSM because the students enjoyed them and they are not bored. (R1)

I think this module can help teachers to respond to learner differences during enrichment activities. ... Apart from that, teachers will know their students better by recognising their strengths, weaknesses and potentials. So teachers can use students' strengths and weaknesses to develop their potential. (R3)

I think teachers should use this module because it tests the level of students' multiple intelligences. (R4)

Finally, as pointed out by R2, the module provided the teachers with ideas to implement enrichment activities in the classroom in the future.

This module gives me ideas and inspiration to develop activities based on MI for my students in the classroom. Before this it was difficult to implement enrichment activities due to lack of ideas. But not anymore. (R2)

\section{DISCUSSION}

According to Wahl (1999), there were various ways that could be used to improve teaching and learning processes. One of them is through the application of MI in teaching and learning activities. Earlier 
studies have shown that the application of MI improved students' achievements (Chan, 2005; Gardner \& Hatch, 1990; Greenhawk, 1997; Kallenbac \& Viens, 2001; Nurulwahida \& Ahmad Azman, 2014). Thus, it is recommended that any enrichment activities conducted to enhance teaching and learning should include the MI concept. The enrichment activities in this study were in line with the suggestions made by earlier studies (Chan, 2005; Kallenbach \& Viens, 2001; Nwagu \& Nwagu, 2013; Pamela, 2001) which focused on the thinking, problem solving and decision making skills based on the eight MI profiles.

The results saw an overall improvement in all areas of intelligences for the treatment group. This clearly indicated the positive effect on the treatment group as compared to the control group which had received conventional teaching approaches. As pointed out in the literature (Gardner, 2004; Gardner \& Hatch, 1990; Kallenbach \& Viens, 2001), the MI-based module, when combined with problem solving, team work and hands on activities tended to increase students' MI scores (see appendix for sample activities). This suggests that improvement in various MI skills is possible when students are involved in meaningful learning experiences such as student-centred activities. This study has showed there was an increase in the multiple intelligence profiles of the students. The findings have strengthened Gardner's (1983) claim that each individual has all eight intelligences (Buschick, Shipton, Winner \& Wise, 2007; Gardner \& Hatch, 1990; Kallenbach \& Viens, 2001; Nurulwahida \& Ahmad Azman 2014; Zaidatun, 2002), but they are at different levels (Ong Chiek Pin, 2001) and that these intelligences can be taught to the students.

In this study, the treatment and control groups scored excellent in mathematics and intrapersonal intelligence, thus failing to reject the related hypotheses. The MRSM students were excellent academic achievers who scored outstandingly in the national exams in Malaysia, including getting an A for Mathematics, which is one of the entry requirements into MRSM (Mohammad Amin, 2007). In the meantime, the students' inclinations towards intrapersonal intelligence were unsurprising since they lived independently in boarding schools away from their family. Their independence could be a factor that explains why they could understand themselves 
better and were able to do self-reflection about their daily lives (Nurulwahida, 2005). This is in line with the MRSM's aspiration to develop in their students the ability to think, to be creative, to invent and to find ways to solve problems effectively (Jamaluddin, 2000). As a whole, the MRSM seems to excel in developing students' logical mathematics and intrapersonal intelligences.

The qualitative analysis of the interview data seemed to suggest that the teachers valued the MI module and the enrichment activities. The teachers believed that the module and activities were responsible for improving students' engagement and inducing awareness of students' different intelligences. At the same time, the activities provided opportunities for students to engage in higher order thinking skills with real life examples (Armstrong, 2003; Kagan \& Kagan, 1998; Kallenbach \& Viens, 2001; McKenzie, 2009). This is in line with Gardner's definition of intelligence as the ability to solve real-life problems and to design products available in the real world.

The teachers commented on three positive elements in the module. Firstly, the objectives were clear and achievable. Miller, Linn \& Gronlund, (2013) stated that for teachers, objectives inform the content and its relevance to students, while for students, objectives means the contents they are required to learn from the module. Thus, it is clear that the objectives provided clear and useful guidance for teachers and students. Secondly, the module provided clear instructions for each activity. This is supported by Valdez et al. (2013) who claimed that clear instructions guide teachers and students in using the module. Thirdly, the enrichment module in this study provided various activities to attract the students' interests by integrating visuals, pictures, charts, graphs, short stories and games to fulfil the strategies for multiple learning resources. Kornhaber, Ferros, \& Veenema, (2004) discovered that multiple applications of MI provided various activities based on students' ability. In a similar vein, Campbell (1990), Ali Riasat (2005) dan Nwagu \& Nwagu (2013) claimed that the integration of multiple activities in students' learning increased their interests and focus to learn. Activities like games, text comprehension and creative writing enable learning to be meaningful. Valdez et al. (2013) reported similar findings that learning by means of modular activities was interesting, challenging and stimulating. 


\section{CONCLUSION}

In conclusion, the findings in this study seemed to suggest that students have multiple intelligences albeit at different levels. The task of a teacher is to celebrate the differences and not focus only on selected intelligences. This can be achieved through making available a variety of activities which allows for different students to showcase their different abilities, skills, and inclinations. The systematic modular enrichment activities highlighted in this study portrays one such example in which MI can be taught effectively. The availability of the module can facilitate busy teachers to vary their teaching approaches to enhance students' learning engagement. Nonetheless, this study is limited to MRSM students who are known to be high achievers. The findings, therefore, are not meant to represent the wider student population. Future replication should include regular schools and non-performing students. Given current students' inclination towards technology, it is recommended that the modular activities be tested using interactive applications.

\section{REFERENCES}

Ali Riasat. (2005). Development and effectiveness of modular teaching in biology at secondary level (Unpublished doctoral dissertation), University of Arid Agriculture, Rawalpindi.

Armstrong, A. (2003). Instructional design in the real world: A view from the trenches. Hershey, PA: Information Science Publishing.

Best, J. W., \& Kahn, J. V. (1998). Research in education (8th ed.). Boston, Mass: Allyn and Bacon.

Braun, V., \& Clarke, V. (2013). Successful qualitative research a practical guide for beginners. Thousand Oaks, California: SAGE Publications.

Buschick, M. E., Shipton, T.A ., Winner, L. M., \& Wise, M. D. (2007). Increasing reading motivation in elementary and middle school students through the use of multiple intelligences (Unpublished master's thesis). Saint Xavier University.

Campbell, D. T., \& Stanley, J. C. (1966). Experimental and quasiexperimental design for research. In N. L., Gage (Ed.), Handbook of research on teaching. Chicago: Rand McNally. 
Campbell, B. (1990). The research results of a multiple intelligences classroom. New Horizons for Learning: On the Beam, 11(1). Zephyr Press.

Campbell, L. (1997). Variations on theme: How teachers interpret MI theory. Educational Leadership 55(1), 30-45.

Chan, W. D. (2005). Perceived multiple intelligences and learning preferences among Chinese gifted students in Hong Kong. Journal for the Education of the Gifted, 29, 187-212.

Chua Yan Piaw. (2009). Statistik penyelidikan lanjutan: Ujian univariat dan multivariat. Kuala Lumpur: McGraw-Hill.

Creswell, J.W. (2012). Educational research: Planning, conducting and evaluating, quantitative and qualitative research (4th ed.). Boston: Pearson Education.

Farland, D. (2006). The effect of historical, nonfiction trade books on elementary students' perceptions of scientists. Journal of Elementary Science Education, 18 (2), 31-47.

Field, A. (2009). Discovering statistics using SPSS (3rd ed.). London. SAGE Publications Ltd.

Gardner, H. (1983). Framed of mind: The theory of multiple intelligence. New York. Basic Books.

Gardner, H., \& Hatch, T. (1990). Multiple intelligences go to school: Educational implications of theory of multiple intelligences. CTE Technical Report. Issue No.4, March.

Gardner, H. (1996). Multiple intelligences. Retrieved from http:// w.w.wedu/-tip/gardner.html.

Gardner, H. (2004). Audiences for the theory of multiple intelligences. Teachers College Record, 106(1), 212-220.

Gardner, H. (2008). 5 minds for the future. Boston: Harvard Business Press.

Greenhawk, J. (1997). Multiple intelligences meet standards. Educational Leadership, 55(1), 62-64.

Sternberg, R. J. (2004). Psychology. United States: Thompson Learning, Inc.

Jamaluddin (2000). Buku panduan guru MRSM. Bahagian Pendidikan Menengah MARA.

Kuala Lumpur: Ibu Pejabat MARA.

Kagan, S., \& Kagan, M. (1998). Multiple intelligences: The complete MI book. San Clemente, CA: Kagan Cooperative Learning.

Kallenbach, S., \& Viens, J. (2001). Adult multiple intelligences study. NCSALL Research Projects. 
Kornhaber, M. L., Ferros, E., \& Veenema, S. (2004). Multiple intelligence: Best ideas from theory and practice. Needham Heights, MA: Allyn \& Bacon.

Mayer, R. G. (1988). Modules from design to implementation. Philippines: The Colombo Plan Staff College.

McKenzie, W. (2000). Multiple intelligences survey. Retreived from http: surfaquarium.com/MI/inventory.htm.

McKenzie, W. (2009). Multiple intelligences and instructional technology (2nd ed.). New Delhi: Viva Books.

Merriam, S. B. (2009). Qualitative research: A guide to design and implementation. San Francisco: Jossey-Bass Inc.

Miller, M. D., Linn, R. L., \& Gronlund, N. E. (2013). Measurement and assessment in teaching (12th ed.). United States: Pearson Education.

Malaysia Ministry of Education. (2006). National education blueprint (2006-2010). Putra Jaya: Education Planning and Policy Research Division.

Mohammad Amin Zakaria (2007). Penilaian pelaksanaan model pengayaan seluruh sekolah (MPSS) untuk pelajar pintar cerdas di Maktab Rendah Sains MARA (MRSM): Satu kajian kes (Tesis Doktor Falsafah). Tidak diterbitkan. Universiti Sains Malaysia.

Nurulwahida \& Ahmad Azman. (2014). The effectiveness of the modular enrichment activities based on Gardner multiple intelligences and Sternberg thinking skills. Journal of Education and Practice, 5 (2), 55-62.

Nurulwahida Azid @ Aziz. (2005). Hubungan pola kepelbagaian kecerdasan Gardner dengan aktiviti schoolwide enrichment model (SEM) di kalangan pelajar Maktab Rendah Sains MARA (Tesis Sarjana). Tidak diterbitkan. Universiti Teknologi Malaysia.

Nwagu, E., \& Nwagu, E. (2013). Effectiveness of multiple intelligences teaching approach in drug education of pupils in Enugu State of Negeria. Journal of Education and Practice, 4 (16), 46-55.

Ong Chiek Pin (2001). Gaya pembelajaran pelajar dan gaya pengajaran guru tingkatan dua di sekolah bandar dan luar bandar di daerah Batu Pahat, Johor (Tesis Sarjana) . Tidak diterbitkan. Universiti Teknologi Malaysia. 
Owalabi, T., \& Okebukola, F. (2009). Improving the reading ability of science students through study groups and multiple intelligences. ERIC Online Submission, US-China. Education Review, 6, 38-44.

Renzulli, J. S. (1985). The three-ring conception of giftedness. A developmental model for creative productivity. South African Journal of Education, 5(1), 1-18.

Valdez, A., Mangorsi, S., Hambre, V. Magdara, D., \& Manalundong, M. (2013). Effects of HOTS Techniques through Modular Instructions in Teaching High School Chemistry in MSUBalindong High School. Journal of e-Education, e-Business, e-Management and e-Learning, 3, 326-329.

Wahl, M. (1999). Multiple intelligences power up math teaching. New Horizons for Learning: On the beam, 4(6). Zephyr Press.

Zaidatun Tasir (2002). Reka bentuk perisian multimedia berasaskan kecerdasan pelbagai pelajar (Tesis Doktor Falsafah). Tidak diterbitkan. Universiti Teknologi Malaysia. 


\section{APPENDIX}

\section{Sampel of enrichment activity}

\section{UNIT 3.1 : AKTIVITI RUANG VISUAL}

\section{Apakah Yang Saya Gambarkan?}

$\checkmark$ Aktiviti ini dilakukan secara individu

$\checkmark$ Pelajar diberi masa 10 minit untuk menyelesaikannya.

$\checkmark$ Tamat masa 10 minit, guru akan memilih satu jawapan pelajar untuk dibacakan di hadapan kelas. Berikan tepukan kepada pelajar berkenaan sebagai tanda penghargaan.

$\checkmark$ Selanjutnya guru akan membacakan jawapan yang disediakan dalam modul supaya pelajar dapat membandingkan jawapan masing-masing.

\section{JAWAPAN}

1. Benda yang boleh diisi sesuatu, kerana tiada satu pun dari kumpulan kedua terdiri daripada benda yang boleh diisi.

2. Haiwan yang boleh dimakan, kerana tiada satu pun daripada kumpulan kedua haiwan yang boleh dimakan.

3. Benda yang diperbuat daripada kaca, kerana tiada satu pun daripada kumpulan kedua diperbuat daripada kaca. 


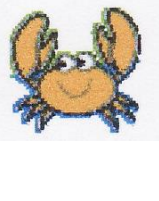

\section{APAKAH YANG SAYA GAMBARKAN?}

Cuba teka apa yang diterangkan oleh contoh-contoh yang diberikan kepada anda. Tuliskan jawapan anda dalam ruangan yang disediakan.

Contoh: Saya sedang memikirkan sesuatu. Ini adalah beberapa contoh: air, susu, dakwat. Ini bukan contoh-contohnya: bertih jagung, pensel, bayam. Apakah yang saya gambarkan?

Jawapan yang betul adalah seperti "cecair". Air, susu dan dakwat adalah cecair. Tiada satu pun dari kumpulan kedua-bertih jagung, pensel dan bayam adalah cecair. Perhatikan bahawa "benda untuk diminum" adalah salah kerana kita

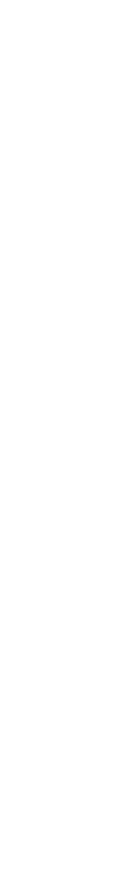

\section{AKTIVITI 1}

Saya sedang memikirkan sesuatu. Ini adalah beberapa contoh: cawan, gelas, beg kertas. Ini bukan contoh-contohnya: sos, garpu, susu. Apakah yang saya gambarkan?Kenapa?

\section{AKTIVITI 2}

Saya sedang memikirkan sesuatu. Ini adalah beberapa contoh: ikan, kambing, ayam. Ini bukan contoh-contohnya: anjing, kuda, tikus. Apakah yang saya gambarkan? Kenapa?

\section{AKTIVITI 3}

Saya sedang memikirkan sesuatu. Ini adalah beberapa contoh: tingkap, tiub lampu, botol. Ini bukan contoh-contohnya: bola sepak, lilin, beg kertas. Apakah yang saya gambarkan?Kenapa? 